\title{
REMOVAL OF Pb(II) FROM AQUEOUS SOLUTION BY NATURAL AND SYNTHETIC
} CALCITES

\author{
Folahan Amoo Adekola ${ }^{1 *}$, Nasiru Abdus Salam ${ }^{1}$, Haleemat Iyabode Adegoke ${ }^{1}$, Ayomadewa \\ Mercy Adesola ${ }^{1}$ and Jacob Ishola Dele Adekeye ${ }^{2}$ \\ ${ }^{1}$ Department of Chemistry, University of Ilorin, Ilorin, Nigeria \\ ${ }^{2}$ Department of Geology and Mineral Sciences, University of Ilorin, Ilorin, Nigeria
}

(Received December 13, 2010; revised October 26, 2011)

\begin{abstract}
A comparative evaluation of the adsorption capacity and kinetics of $\mathrm{Pb}$ (II) uptake by both synthetic and natural calcites has been undertaken using batch equilibration technique. The originality of the calcite materials was confirmed by XRD and elemental composition by XRF. The point of zero charge values of 9.57 and 8.20 were obtained by mass titration method for synthetic and natural calcite, respectively. The maximum adsorption capacities of $200 \mathrm{mg} / \mathrm{g}$ and $150 \mathrm{mg} / \mathrm{g} \mathrm{Pb}$ (II) of synthetic calcite and natural calcite were obtained at initial lead loading of $1200 \mathrm{mg} / \mathrm{L}$ at $25 \pm 2{ }^{\circ} \mathrm{C}$, respectively. The study showed a very slight dependence of sorption capacity on the ionic strength and $\mathrm{pH}$, but a strong dependence on the particle size and contact time. The sorption data results fitted better the Langmuir than the Freundlich isotherms. The kinetic data fitted well to pseudo-first order sorption kinetic model with a regression coefficient value of 0.96 and 0.94 for synthetic and natural calcites, respectively. Desorption of $\mathrm{Pb}$ (II) from calcite surface was achieved with efficiency of $95 \%$ using $4 \mathrm{M} \mathrm{HNO}_{3}$. The extent of reversibility of sorption reaction was a function of the equilibrium $\mathrm{pH}$ of calcite- $\mathrm{Pb}$ (II) solution suspension.
\end{abstract}

KEY WORDS: Pb(II), Calcite, Sorption, Kinetics, Desorption, Aqueous solution

\section{INTRODUCTION}

Heavy metals are widely spread in the environment and they could be of anthropogenic or natural origin. Heavy metals in aquatic media are considered to be hazardous to both plants and animals, and their effect could be direct or indirect. Several industrial operations release some of these heavy metals in their effluents, which eventually find their way into water sources such as lakes, rivers and streams [1].

Lead is a very important metal used in the industry due to its low melting point and ability to form stable compounds. Sources of $\mathrm{Pb}$ in the environment include paints, batteries, cable sheathing, extruded products, cosmetics and petroleum products [2].

When $\mathrm{Pb}$ is released into the lakes, rivers and streams as effluents, they constitute pollutants thus rendering the water harmful to aquatic organisms. The non-biodegradability of $\mathrm{Pb}$ results in its bioaccumulation in living organisms causing serious health disorders [3]. This is as a result of its long residence time in the environment. Some of the health effects of $\mathrm{Pb}$ include kidney damage, anaemia, cancerous diseases, nervous disorder and eventually death following prolonged exposure. $\mathrm{Pb}$ has also been associated with cognitive development in children, sudden infant death and still birth [4-6]. Several methods have been documented in the literature viz-a-viz the removal of heavy metals and especially $\mathrm{Pb}$ (II) from aqueous solutions. These methods include electro-deposition, cementation, reverse osmosis, membrane process, solvent extraction and adsorption [7]. Most of these methods present the inconvenience of high cost, large organic solvent consumption, requiring high level of expertise.

Calcite $\left(\mathrm{CaCO}_{3}\right)$ is one of the most common minerals on the surface of the earth comprising about $4 \%$ of the earth's crust and is formed in many different geological environments [8].

*Corresponding author. E-mail: ihalimat@yahoo.com 
Calcite can form rocks of considerable masses and constitutes a significant part of all three major rock classification types. Several researchers have worked on the sorption of various heavy metals using calcite as the adsorbent [9-15]. The difference between metal sorption capacities may be due to their affinity for the surface of calcite. The maximum adsorption capacities of most natural calcite reported in the literature are generally low. Most of the calcites investigated were concentrated in Asia, Latin America and Europe. So there is the need to continue search for indigenous calcite with high sorption capacity.

Assessing $\mathrm{Pb}$ (II) interactions with mineral surfaces is essential for the prediction of the metal's mobility and its potential availability. Due to the ubiquity and reactivity of calcite in natural systems and high affinity of $\mathrm{Pb}$ (II) for the calcite sorbent [16], this mineral presents a viable substrate for effective $\mathrm{Pb}$ (II) retention. Potential sorption mechanism includes inner or outer sphere adsorption on the surface of calcite combined with co-precipitation of discrete $\mathrm{Pb}^{2+}$ with dissolved carbonate phases [17].

The objectives of the present study are to determine the capacity and kinetics of $\mathrm{Pb}$ (II) sorption on both natural and synthetic calcites as a function of particle size, ionic strength and $\mathrm{pH}$, and determine conditions for desorption of pre-sorbed lead from the surface of calcites.

\section{EXPERIMENTAL}

\section{Collection and preparation of sample}

The natural calcite used was obtained from the Department of Geology, University of Ilorin, Ilorin, Nigeria, and it originated from Isanlu-Isin in the North-Central region of Nigeria. The natural calcite was ground and then sieved into various particle sizes. These are $\phi<150 \mu \mathrm{m}$, $\phi$ $<212 \mu \mathrm{m}$ and $\phi>212 \mu \mathrm{m}$. Each fraction was washed with de-ionized water to remove any adhering dust particles on the surface of calcite grains several times with constant stirring. The sample was filtered and air dried for $5 \mathrm{~h}$ and then separated into different particle sizes. The synthetic calcite was prepared in the laboratory following a standard procedure [18]. Calcite was synthesized from the reaction of sodium carbonate and calcium chloride solutions at $26 \pm 2{ }^{\circ} \mathrm{C}$ Equal volumes of $1 \mathrm{M} \mathrm{Na}_{2} \mathrm{CO}_{3}$ and $1 \mathrm{M} \mathrm{CaCl}_{2}$ solutions were taken, reacted and then allowed to stand for a period of half of an hour. White precipitate was formed which was filtered and then, air dried for a period of $24 \mathrm{~h}$. All reagents used were of analytical grade and were from BDH or Sigma Aldrich, Germany.

The specific gravity was determined by gravimetric method. The calcium constituent was determined by EDTA method after digesting duplicate masses of the calcite material and the concentrations of other different elements were determined using Atomic absorption spectrometer S series 711430VI.26.

The mineralogy of both natural and synthetic calcites was determined by X-ray diffraction (XRD), MD-10 X-ray Diffractometer. The adsorbents were also examined for structural characteristics by Infrared spectrophotometer, model Nicolet Acatar FT-IR 330 using KBr pellets.

The point of zero charge was defined as the $\mathrm{pH}$ at which the material takes a net zero surface charge [19]. The point of zero charge was determined using mass titration method [20]: various masses of calcite were weighed $(0.5-2.0 \mathrm{~g})$ and added to $25 \mathrm{~mL}$ of $\mathrm{KNO}_{3}$ of different ionic strength $\left(10^{-3}-10^{-1} \mathrm{M}\right)$. The $\mathrm{pH}$ values of the suspensions were noted before and after equilibration for $24 \mathrm{~h}$. The suspensions were placed on Mk V orbital mechanical shaker at a speed of $250 \mathrm{rpm}$ for $24 \mathrm{~h}$ and the $\mathrm{pH}$ values were taken and also recorded after the equilibration time. The acid consumption effect on the PZC was determined by adding small volume of $0.01 \mathrm{M} \mathrm{HNO}_{3}$ to the suspension to bring the $\mathrm{pH}$ values down to between 5 and 6 and the suspensions were equilibrated for another period of $24 \mathrm{~h}$, and the final $\mathrm{pH}$ values were 
taken and recorded. Basic solution effect on the PZC was also undertaken using $0.01 \mathrm{M} \mathrm{NaOH}$. A model PHS $25 \mathrm{pH}$ meter was used to determine the $\mathrm{pH}$ of the solution.

\section{Batch experiments}

Various concentrations of $\mathrm{Pb}(\mathrm{II})$ solution between $(20-2000 \mathrm{mg} / \mathrm{L})$ were prepared from the stock solution by serial dilution. $50 \mathrm{~mL}$ of each concentration was contacted with a fixed amount of each calcite material at ambient temperature. The suspensions were equilibrated for $24 \mathrm{~h}$ on $\mathrm{Mk}$ $\mathrm{V}$ orbital shaker at a speed of $150 \mathrm{rpm}$. After the equilibration period, each suspension was filtered using Whatman filter paper of diameter $125 \mathrm{~mm}$; the concentration of $\mathrm{Pb}$ (II) left in the filtrate was determined using AAS. The amount of $\mathrm{Pb}$ (II) fixed per gram was then calculated using the equation below:

$$
\mathrm{Q}_{\mathrm{e}}=\mathrm{v}\left(\mathrm{C}_{\mathrm{i}}-\mathrm{C}_{\mathrm{e}}\right) / \mathrm{m}
$$

where $\mathrm{Q}_{\mathrm{e}}$ - quantity sorbed at equilibrium in $\mathrm{mg} / \mathrm{g}, \mathrm{C}_{\mathrm{i}}$ - initial concentration of metal in solution in $\mathrm{mg} / \mathrm{L}, \mathrm{C}_{\mathrm{e}}$ - equilibrium concentration of metal solution in $\mathrm{mg} / \mathrm{L}, \mathrm{v}$ - volume of lead solution used in litres, $\mathrm{m}$ - mass of calcite used in grams.

A plot of quantity sorbed versus initial concentration of the metal was made to determine the sorption capacity of the material. The concentration corresponding to the highest quantity of calcite material sorbed was taken and used for subsequent experiments.

\section{Sorption kinetics}

Sorption kinetics was done to fix the equilibrium time of reaction. $1200 \mathrm{mg} / \mathrm{L}$ of $\mathrm{Pb}$ (II) solution was used at a $\mathrm{pH}$ value of 2.5. Fixed mass of the calcite was contacted with the $\mathrm{Pb}$ (II) solution at different time interval of between $5 \mathrm{~min}$ and $24 \mathrm{~h}$. The solution was filtered at each time interval and then analyzed for $\mathrm{Pb}$ (II) using AAS. The plot of quantity sorbed against time was made and the equilibrium time was determined from the plot. This time was used for subsequent experiments. The influence of $\mathrm{pH}$, ionic strength and particle size were investigated using the following procedures.

\section{Determination of the effect of ionic strength}

To determine the effect of ionic strength on the sorption capacity, the ionic strength was varied between $10^{-3}-10^{-1} \mathrm{M} \mathrm{KNO}_{3}$. Mass corresponding to each ionic strength was weighed and added to $50 \mathrm{~mL}, 1200 \mathrm{mg} / \mathrm{L} \mathrm{Pb}\left(\mathrm{NO}_{3}\right)_{2}$ containing a fixed amount of calcite material. The $\mathrm{pH}$ values of the suspension before and after addition of $\mathrm{KNO}_{3}$ was taken and recorded. The suspension was contacted for $2 \mathrm{~h}$ and then filtered so that the amount of $\mathrm{Pb}$ (II) left in the solution can be determined and the quantity sorbed was calculated using equation (1) above. The curve of quantity sorbed against ionic strength was plotted.

\section{Determination of the effect of particle size}

The effect of particle size of calcite on the sorption capacity was studied using the sizes $\phi<150$ $\mu \mathrm{m}, \phi<212 \mu \mathrm{m}$ and $\phi>212 \mu \mathrm{m}$ as described above. Fixed amount of the calcite was weighed and added to $50 \mathrm{~mL}$ of $1200 \mathrm{mg} / \mathrm{L}$ of $\mathrm{Pb}\left(\mathrm{NO}_{3}\right)_{2}$ solutions. The suspension was contacted for $2 \mathrm{~h}$ and then filtered and analyzed for the amount of $\mathrm{Pb}(\mathrm{II})$ that was not sorbed. The amount sorbed was calculated using equation (1) above. 
Determination of the effect of $\mathrm{pH}$

The effect of $\mathrm{pH}$ on sorption capacity was studied over $\mathrm{pH}$ values of 3 to 11 . The $\mathrm{pH}$ was adjusted by adding $0.01 \mathrm{M} \mathrm{HNO}_{3}$ or $0.1 \mathrm{M} \mathrm{KOH}$. The ionic strength of the suspensions was fixed to a particular value as determined from the result of the previous section. $50 \mathrm{~mL}$ of $\mathrm{Pb}(\mathrm{II})$ solutions of different $\mathrm{pH}$ values between the limit specified above were prepared. A fixed amount of calcite and a calculated amount of $\mathrm{KNO}_{3}$ were added to the suspensions to fix their ionic strength. The $\mathrm{pH}$ values of the suspensions were taken after the addition of the material. There was no significant change in the $\mathrm{pH}$ values. The suspensions were agitated for $2 \mathrm{~h}$, filtered and the amount sorbed per gram from each suspension was calculated. A plot of quantity sorbed versus $\mathrm{pH}$ values were made to determine the effect of varying $\mathrm{pH}$ on the sorption of $\mathrm{Pb}(\mathrm{II})$.

\section{Desorption studies}

Desorption experiment was carried out at different $\mathrm{pH}$ values ranging from 1-9. Fixed amount of calcite was contacted with $50 \mathrm{~mL}, 1200 \mathrm{mg} / \mathrm{L}$ of $\mathrm{Pb}\left(\mathrm{NO}_{3}\right)_{2}$ solution for $2 \mathrm{~h}$ at a temperature of $298 \mathrm{~K}$. The suspensions were filtered and the solid particles were used for the desorption experiment. Various concentration of nitric acid solutions were prepared ranging from $\left(4-10^{-5}\right.$ $\mathrm{M})$. The previously sorbed $\mathrm{Pb}$-calcites were then added to $50 \mathrm{~mL}$ of each nitric acid solution. The suspensions were contacted for $2 \mathrm{~h}$, later filtered and analyzed for $\mathrm{Pb}$ on AAS. The quantity of $\mathrm{Pb}$ (II) released from already used calcite was then calculated. The percentage of $\mathrm{Pb}(\mathrm{II})$ desorbed was calculated using equation (2) below. The percentage desorbed was plotted against the various $\mathrm{pH}$ values.

$\%$ of $\mathrm{Pb}$ desorbed $=\left(\mathrm{C}_{\mathrm{f}} \times 100\right) / \mathrm{C}_{\mathrm{i}}$

where $C_{i}$ - initial concentration of lead used for sorption process and $C_{f}$ - final concentration of lead after desorption.

\section{Isotherm application}

The data obtained from the sorption studies were fitted to Langmuir, Freundlich and Temkin adsorption model at a temperature of $25 \pm 2{ }^{\circ} \mathrm{C}$ to analyze adsorption isotherms in order to estimate the adsorption constants. The isotherm that best fit the data using linear regression coefficient was deducted there from.

Adsorption kinetics

The kinetic data of $\mathrm{Pb}$ (II) sorption were analyzed using pseudo first order and second order models. The equilibrium quantity sorbed was determined using equation (1) above. The linear regression values of the two models were determined to know the model that best fit the sorption process and the rate constants were determined at a temperature of $25 \pm 2{ }^{\circ} \mathrm{C}$.

All the above experiments were performed for both the natural and synthetic calcite samples. A comparative analysis was done in terms of kinetics, adsorption capacity, influence of ionic strength and $\mathrm{pH}$ on $\mathrm{Pb}$ (II) sorption by the calcite samples.

\section{Physical properties}

\section{RESULTS AND DISCUSSION}

The physicochemical characteristics of calcite samples used in this work are summarized in Table 1. 
Table 1. Physicochemical characteristics of calcite samples.

\begin{tabular}{|l|l|l|}
\hline Property & Natural & Synthetic \\
\hline Colour & White & White \\
\hline Texture & Fine & Fine \\
\hline Density $\mathrm{g} / \mathrm{cm}^{3}$ & 2.5 & 2.3 \\
\hline$\%(\mathrm{w} / \mathrm{w}) \mathrm{Ca}$ & $39.2 \%$ & $39.6 \%$ \\
\hline$\%(\mathrm{w} / \mathrm{w}) \mathrm{Pb}$ & $1.3 \%$ & $0.8 \%$ \\
\hline$\%(\mathrm{w} / \mathrm{w}) \mathrm{Mg}$ & $1.3 \%$ & $0.5 \%$ \\
\hline $\mathrm{PZC}$ & 8.20 & 9.57 \\
\hline
\end{tabular}

The amount of $\mathrm{Ca}$ present in the sample is very close to the theoretical value of $40 \%$ obtained from the formula of calcite $\left(\mathrm{CaCO}_{3}\right)$. Other impurities found in the samples were $\mathrm{Pb}$ and $\mathrm{Mg}$. The results of determination of point of zero charge (PZC) for both natural and synthetic calcites at different ionic strengths are illustrated in Figures 1a-f. The values of 8.20 and 9.57 were obtained for natural and synthetic calcites, respectively. The higher percentage of impurities in natural calcite could account for its lower PZC value compared to synthetic calcite. These results were in agreement with the values 8-9 reported by Marek [21]. The plateau shows that the surface of the adsorbent does not have affinity for ions anymore.

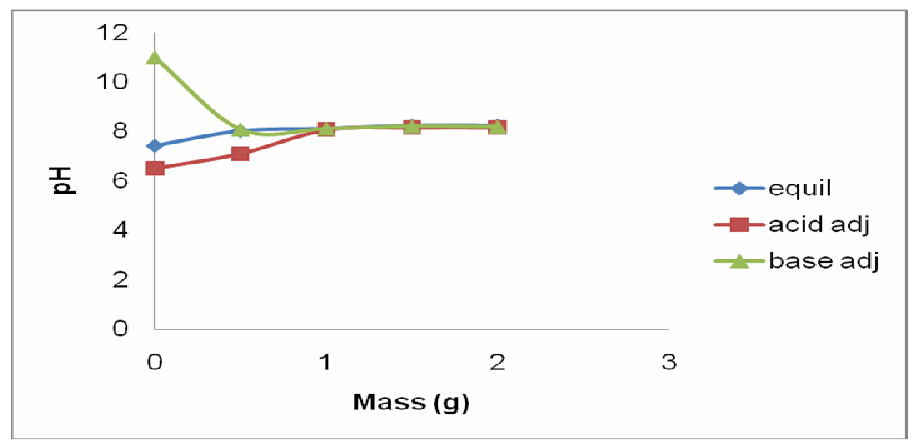

Figure 1a. Plot of $\mathrm{pH}$ versus mass of natural calcite in $0.001 \mathrm{M} \mathrm{KNO}_{3}$.

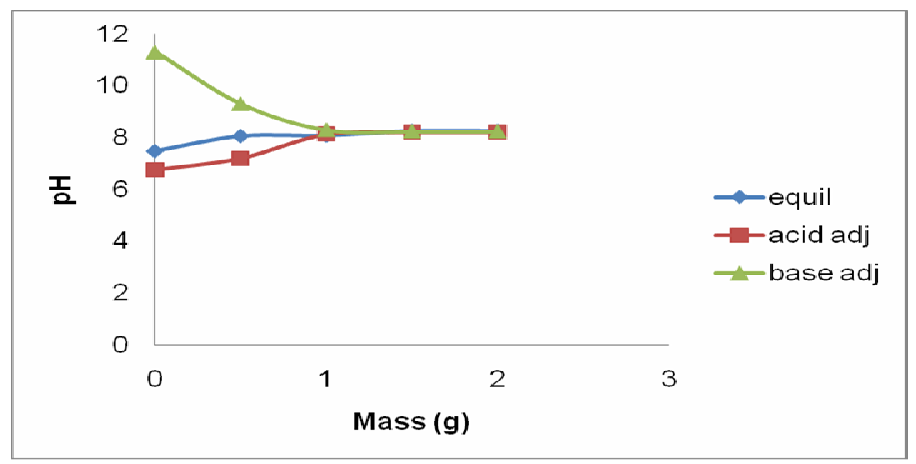

Figure 1b. Plot of $\mathrm{pH}$ versus mass of natural calcite in $0.01 \mathrm{M} \mathrm{KNO}_{3}$. 


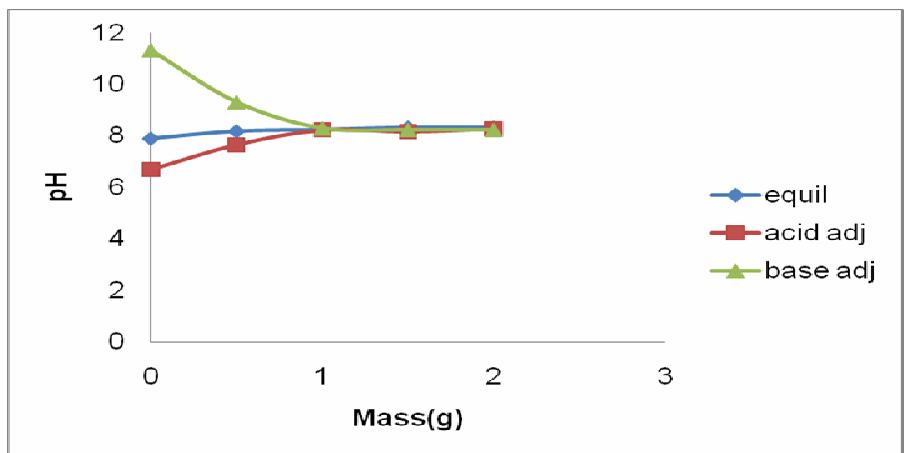

Figure 1c. Plot of $\mathrm{pH}$ versus mass of natural calcite in $0.1 \mathrm{M} \mathrm{KNO}_{3}$.

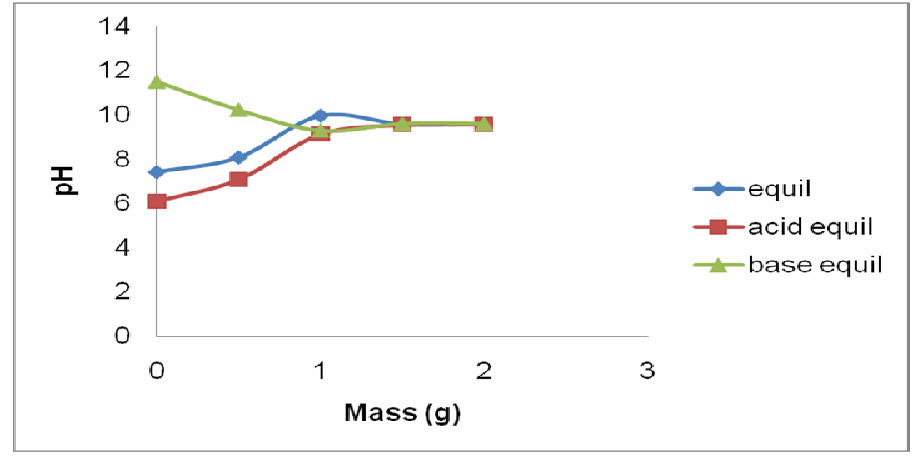

Figure 1d. Plot of $\mathrm{pH}$ versus mass of synthetic calcite in $0.001 \mathrm{M} \mathrm{KNO}_{3}$.

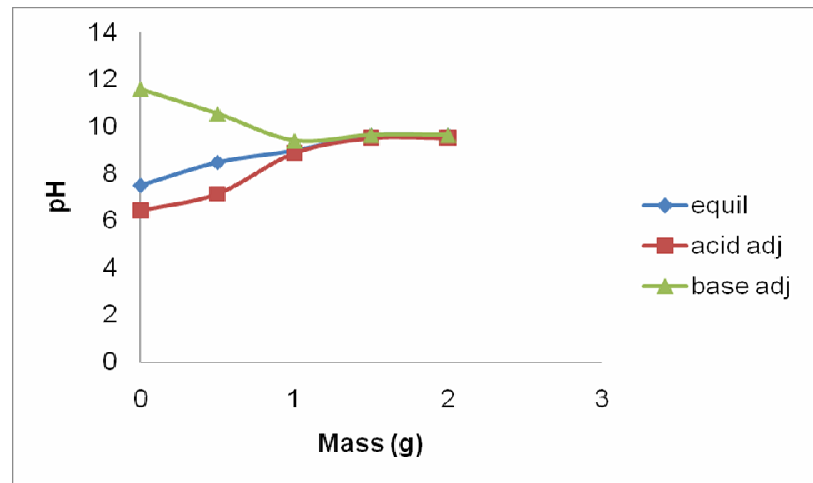

Figure 1e. Plot of $\mathrm{pH}$ versus mass of synthetic calcite in $0.01 \mathrm{M} \mathrm{KNO}_{3}$. 


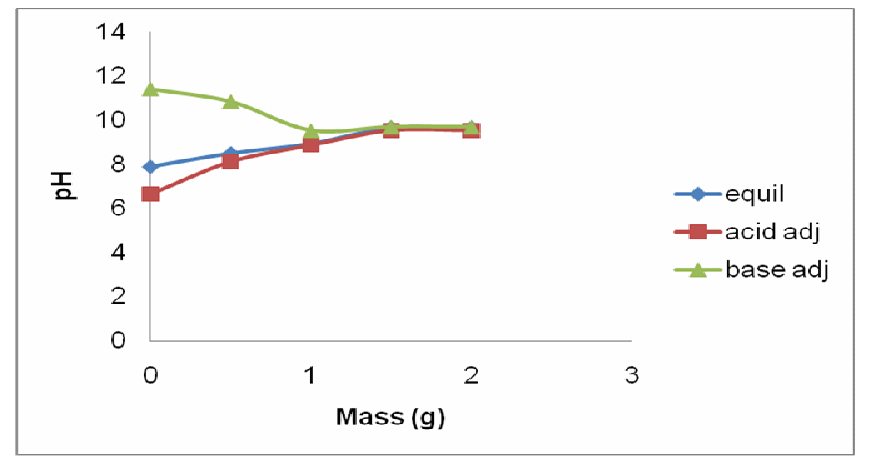

Figure 1f. Plot of $\mathrm{pH}$ versus mass of synthetic calcite in $0.1 \mathrm{M} \mathrm{KNO}_{3}$.

\section{Solubility of calcite}

The results of the solubility of calcite with respect to $\mathrm{pH}$ at different ionic strengths are given in Table 2 for natural and synthetic calcites, respectively. The solubility of the materials increases with $\mathrm{pH}$ up to a $\mathrm{pH}$ value of 6 or 7 where it has the highest solubility and then the solubility drops. Percentage solubility decreases with increasing ionic strength. Natural calcite has a low solubility when compared to synthetic calcite and this can be attributed to the impurities which may be present in the natural material.

Table 2.Percentage of natural and synthetic calcite dissolved as a function of $\mathrm{pH}$ and $\mathrm{KNO}_{3}$ concentration.

\begin{tabular}{|l|l|l|l|l|l|}
\hline $\mathrm{pH}$ & $\begin{array}{l}0.001 \\
\mathrm{KNO}_{3} \\
\text { natural }\end{array}$ & $\begin{array}{l}0.01 \\
\mathrm{KNO}_{3} \\
\text { natural }\end{array}$ & $\begin{array}{l}0.1 \\
\mathrm{KNO}_{3} \\
\text { natural }\end{array}$ & $\begin{array}{l}0.001 \\
\mathrm{KNO}_{3} \\
\text { synthetic }\end{array}$ & $\begin{array}{l}0.1 \mathrm{KNO}_{3} \\
\text { synthetic }\end{array}$ \\
\hline 3 & 0.23 & 0.1 & 0.04 & 0.45 & 0.26 \\
\hline 4 & 0.26 & 0.14 & 0.05 & 0.44 & 0.26 \\
\hline 5 & 0.39 & 0.17 & 0.09 & 0.41 & 0.32 \\
\hline 6 & 0.46 & 0.18 & 0.16 & 0.48 & 0.35 \\
\hline 7 & 0.24 & 0.13 & 0.05 & 0.46 & 0.32 \\
\hline 8 & 0.23 & 0.09 & 0.08 & 0.32 & 0.46 \\
\hline
\end{tabular}

The solubility data show that calcite samples were not readily soluble as less than $1 \%$ of the solid was dissolved in all cases. It is therefore a stable material at the $\mathrm{pH}$ and ionic strength ranges investigated.

\section{Sorption capacity}

The plot of quantity of $\mathrm{Pb}$ (II) sorbed against initial concentration of $\mathrm{Pb}$ (II) solution is shown in Figure 2 for both natural and synthetic calcites. The equilibrium concentration of $\mathrm{Pb}$ (II) was determined from the curve as the concentration in which there was no further increase in quantity sorbed with increasing concentration. This value is $1200 \mathrm{mg} / \mathrm{L}$ for both samples and this concentration was therefore used for subsequent experiments. The maximum sorption capacity for synthetic calcite, which is $200 \mathrm{mg} / \mathrm{g}$, is higher than that of natural calcite, which is $150 \mathrm{mg} / \mathrm{g}$. This can be largely attributed to the higher percentage of calcite content in synthetic than the natural one. As the operational $\mathrm{pH}$ is near neutral, there is greater tendency for the 
synthetic with higher PZC to sorb more quantity of $\mathrm{Pb}$ (II) than natural calcite. These maximum adsorption capacities are considerably higher than some of the previously reported values. For instance, values of 19.92 and $40 \mathrm{mg} / \mathrm{g}$ were reported for a Turkish natural calcite [22] and a Mexican calcitic limestone [23]. Kozar et al. used a commercial $\mathrm{CaCO}_{3}$ for the adsorption of $\mathrm{Pb}$ (II) and $\mathrm{Cd}(\mathrm{II})$ ions from a Calcareous Krka river of various salinity. Their results suggest that $\mathrm{Pb}$ (II) ion remained firmly bound to calcite at all salinities [24]. The maximum adsorption capacities of $\mathrm{Zn}$ (II), $\mathrm{Pb}$ (II) and $\mathrm{Co}$ (II) ion from aqueous solution reported for Jordan natural sorbent of primary mineral (i.e. quartz and aluminosilicates) and a secondary mineral (i.e. calcite and dolomite) are 2.860, 0.320, $0.076 \mathrm{mmol}_{\text {cation }} \mathrm{g}^{-1}$ at $\mathrm{pH}$ 6.5, 4.5 and 7.0, respectively [25].

Naturally occurring minerals (talc, chalcopyrite and barite) have been reported for the removal of $\mathrm{Pb}$ (II) ions from liquid wastes. The adsorption isotherms obtained from the Langmuir and Freundlich equations were generally linear. It was observed that equilibrium time of adsorption was $72 \mathrm{~h}$ at an optimum $\mathrm{pH}$ from 7 to 9 . They also observed that the chalcopyrite fraction $(\phi<63 \mu \mathrm{m})$ has a higher capacity of $99 \%$ to adsorb $\mathrm{Pb}(\mathrm{II})$ ions than the fraction $63-150$ $\mu \mathrm{m}(71 \%)$. The order of adsorption capacity for fractions $\phi<63 \mu \mathrm{m}$ and $63-150 \mu \mathrm{m}$ is chalcopyrite $>$ talc $>$ barite [26]

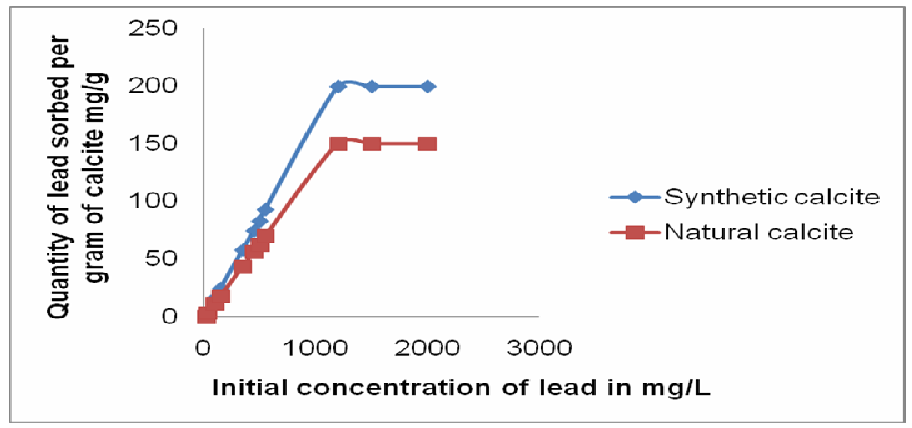

Figure 2. Quantity of $\mathrm{Pb}$ (II) sorbed (mg/g) versus initial $\mathrm{Pb}$ (II) concentration in $\mathrm{mg} / \mathrm{L}$ for natural and synthetic calcite.

\section{Kinetics of sorption}

The results of quantity of $\mathrm{Pb}$ (II) sorbed as a function of the time of contact are summarized in Figure 3. There was a rapid increase in quantity sorbed by natural calcite within the first $60 \mathrm{~min}$ followed by a slight increase before attaining a plateau at $120 \mathrm{~min}$. The result is the same for synthetic calcite only that the rapid increase was in the first $30 \mathrm{~min}$ synthetic and natural calcites. The optimum contact time for the two materials is therefore $120 \mathrm{~min}$. After this time the quantity sorbed remained the same. This equilibrium time of $2 \mathrm{~h}$ has been found to be half that of $4 \mathrm{~h}$ reported by Rouff et al. [14]. The contact time was therefore fixed at $2 \mathrm{~h}$ for subsequent experiments.

\section{Effect of ionic strength}

The results of the effect of ionic strength on the sorption capacity are illustrated in Figure 4 . The results show that ionic strength has very little or no effect on the sorption of lead by calcite. This can be attributed to the high buffering capacity of calcium carbonate which does not allow for significant $\mathrm{pH}$ change that could have resulted from variation of ionic strength. The $\mathrm{pH}$ remains practically constant in the range 4.3-4.6 for natural and 5.1-5.9 for synthetic and the sorption 
capacity of $\mathrm{Pb}$ (II) remained practically the same at $200 \mathrm{mg} / \mathrm{g}$ of $\mathrm{Pb}$ (II) per gram of synthetic and $150 \mathrm{mg} / \mathrm{g}$ of $\mathrm{Pb}$ (II) per gram of natural calcite.

This result is in agreement with the work carried out by Rouff et al. [27] who recorded little effect of ionic strength and $\mathrm{pH}$ on $\mathrm{Pb}$ (II) interactions with calcite. Other researchers have also observed very mild effect of ionic strength and $\mathrm{pH}$ on the $\mathrm{Pb}^{2+}$ sorption on Zeolitized tuffs [28] and on montmorillonite [29].

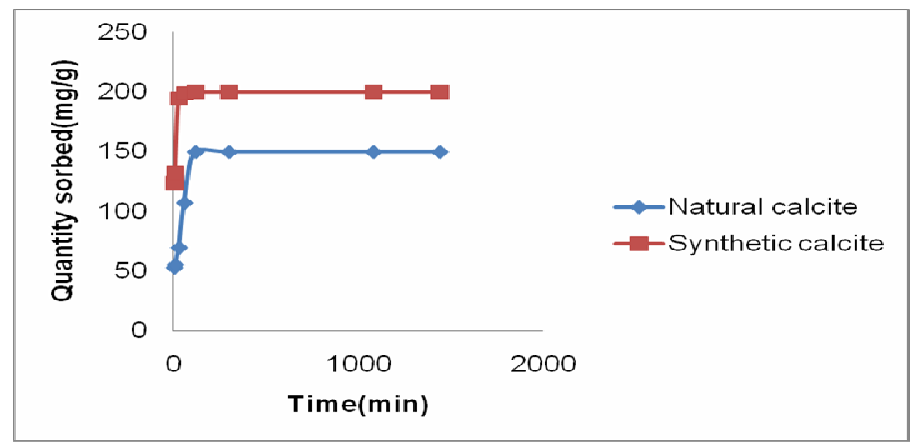

Figure 3. The plot of quantity of $\mathrm{Pb}$ (II) sorbed $(\mathrm{mg} / \mathrm{g}$ ) against contact time (min) for both

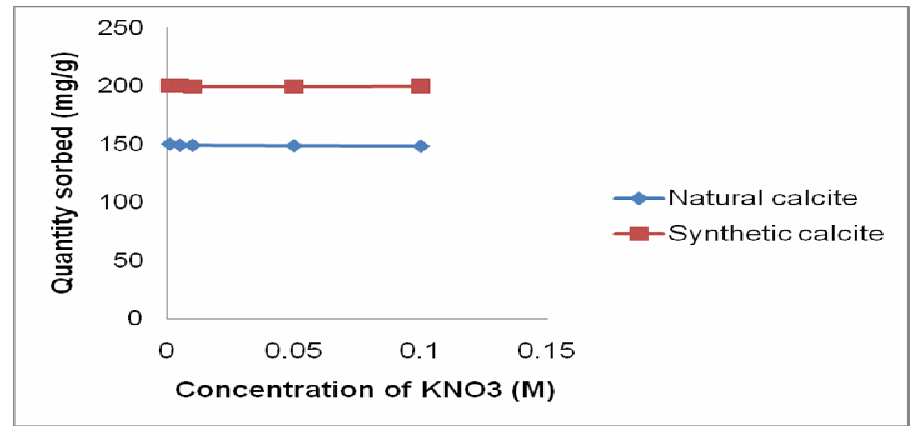

Figure 4. The plot of sorption capacity against ionic strength.

\section{Effect of particle size}

The results of the effect of particle sizes on the sorption capacity are summarized in Table 3 . The quantity sorbed increases with decrease in particle size since many smaller particles present higher surface area than larger particles [30]. This explains why particle size of $\phi<150 \mu \mathrm{m}$ (which is finer than all other particles) has highest sorption capacity while $\phi>212 \mu \mathrm{m}$ has the least.

Table 3. Sorption capacity versus particle size of natural calcite.

\begin{tabular}{|l|l|}
\hline Particle size $(\mu \mathrm{m})$ & Quantity sorbed $(\mathrm{mg} / \mathrm{g})$ \\
\hline$\phi>212$ & 63 \\
\hline$\phi 150-212$ & 73 \\
\hline$\phi<150$ & 150 \\
\hline
\end{tabular}




\section{Effect of $p H$}

There is practically no effect of $\mathrm{pH}$ on the sorption capacity of both natural and synthetic calcites. For natural calcite, sorption capacity varied between 150 and $152 \mathrm{mg} / \mathrm{g}$, while that of synthetic varied between 202 and $203 \mathrm{mg} / \mathrm{g}$ when $\mathrm{pH}$ is varied between 3 and 12. A similar observation of very slight effect of $\mathrm{pH}$ on calcite sorption has been reported by some authors [27-29].

\section{Isotherm studies}

Sorption parameters (the quantity sorbed at equilibrium, $\mathrm{Q}_{\mathrm{e}}$ in $(\mathrm{mg} / \mathrm{g}$ ) and equilibrium concentration of metal solution, $\left.\mathrm{C}_{\mathrm{e}}(\mathrm{mg} / \mathrm{L})\right)$ were subjected to both Freundlich and Langmuir equation, and these are shown in Figure 5a-d and isotherms were plotted for the data in Table 4.

Table 4. Linearized Langmuir isotherm data for the sorption of $\mathrm{Pb}$ on natural and synthetic calcite.

\begin{tabular}{|l|l|l|l|}
\hline $1 / \mathrm{Qe}$ & $1 / \mathrm{Ce}$ & $1 / \mathrm{Qe}$ & $1 / \mathrm{Ce}$ \\
\hline 0 & 0.0025 & 0 & 0.05 \\
\hline 0.21 & 1 & 0.014 & 0.17 \\
\hline 0.0016 & 0.03 & 0.067 & 0.03 \\
\hline 0.012 & 0.002 & 0.067 & 0.13 \\
\hline 0.005 & 0.003 & $1 / \mathrm{Qe}$ & $1 / \mathrm{Ce}$ \\
\hline
\end{tabular}

Where $\mathrm{Q}_{\mathrm{e}}$ - quantity sorbed at equilibrium in $\mathrm{mg} / \mathrm{g}$ and $\mathrm{C}_{\mathrm{e}}$ - equilibrium concentration of metal solution in $\mathrm{mg} / \mathrm{L}$.

The experimental data were statistically processed by linear regression. The regression equations of $y=a x+b$ type and the values obtained for the correlation coefficients, $R^{2}$, are summarized in Table 5. The results in Table 5 show that Freundlich isotherm and Langmuir exhibited acceptable fittings to the experimental data $\left(\mathrm{R}^{2}>0.9\right)$. Langmuir isotherm however has a better fitting with $\mathrm{R}^{2}$ of 0.994 for natural and 0.998 for synthetic calcite.

Table 5. Summary of adsorption constants for linearised Freundlich and Langmuir isotherms at $298 \mathrm{~K}$.

\begin{tabular}{|l|l|l|l|}
\hline Isotherms & Adsorption constants & Natural & Synthetic \\
\hline Freundlich & $\mathrm{K}_{\mathrm{r}}(\mathrm{mg} / \mathrm{g})$ & 9.12 & 9.69 \\
\cline { 2 - 4 } & $\mathrm{N}(\mathrm{g} / \mathrm{L})$ & 1.94 & 1.89 \\
\cline { 2 - 4 } & $\mathrm{R}^{2}$ & 0.931 & 0.895 \\
\cline { 2 - 4 } & $\mathrm{K}_{\mathrm{a}}(\mathrm{l} / \mathrm{mg})$ & 0.0282 & 0.178 \\
\hline \multirow{5}{*}{ Langmuir } & $\mathrm{Q}_{\mathrm{m}}(\mathrm{mg} / \mathrm{g})$ & 167 & 27.8 \\
\cline { 2 - 4 } & $\mathrm{R}^{2}$ & 0.994 & 0.998 \\
\hline
\end{tabular}

Where $\mathrm{K}_{\mathrm{r}}$ and $\mathrm{n}$ are Freundlich constants corresponding to adsorption capacity and adsorption intensity, respectively, $1 / \mathrm{n}$ is the reciprocal of adsorption energy, $\mathrm{K}_{\mathrm{a}}(1 / \mathrm{mg})$ and $\mathrm{Q}_{\mathrm{m}}(\mathrm{mg} / \mathrm{g})$ are Langmuir constants representing energy of sorption and maximum monolayer sorption capacity, respectively, and $\mathrm{R}^{2}$ is the correlation coefficient.

The Freundlich constants $\left(\mathrm{K}_{\mathrm{r}}\right.$ and $\left.\mathrm{n}\right)$ are indications of favourable or unfavourable adsorption onto adsorbent surface [31]. The intercept is an indication of sorption capacity and the slope is an indication of sorption intensity. A relatively slight slope $\mathrm{n}<<1$ indicates that sorption intensity is good over the entire range of concentration studied while a steep slope of $n$ $>1$ indicates that sorption intensity is good at high concentration but much less at lower concentration [25, 31]. A high value of $K_{r}$ is indicative of high sorption capacity [32]. The $n$ values of both materials fall in the range $2-10$ which indicate that the sorption intensity is good 
at high concentration [32]. The $\mathrm{K}_{\mathrm{r}}$ values obtained indicate a higher sorption capacity for natural calcite than synthetic. Langmuir isotherm, fit well for both calcite with $\mathrm{R}^{2}=0.931$ and 0.895 for natural and synthetic, respectively.

In contrast to the report of Al-Degs et al. [25], Langmuir isotherm has the best application for $\mathrm{Pb}$ (II) sorption on calcite. The predicted maximum sorption capacity $\left(\mathrm{Q}_{\max }\right.$ was $167 \mathrm{mg}$ of $\mathrm{Pb}$ per gram of calcite for natural and $27.8 \mathrm{mg}$ of $\mathrm{Pb}$ per gram of calcite for synthetic calcite. The values are in good agreement with the measured values of $150 \mathrm{mg} / \mathrm{g}$ and $200 \mathrm{mg} / \mathrm{g}$ for natural and synthetic calcites, respectively.

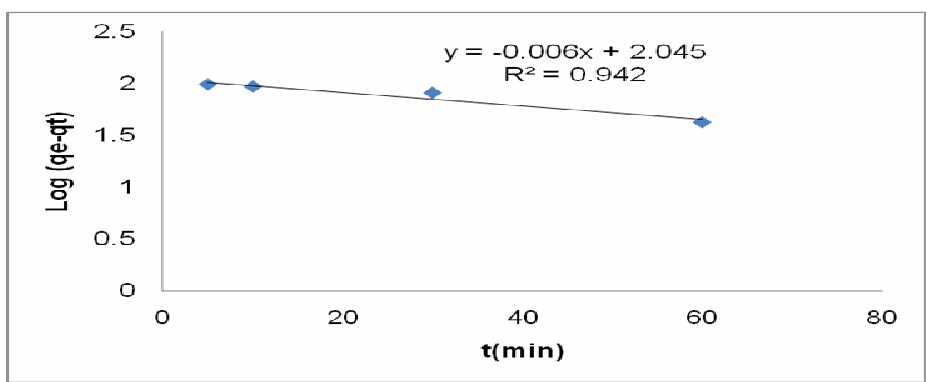

Figure 5a. Pseudo $1^{\text {st }}$ order graphical illustration for natural calcite.

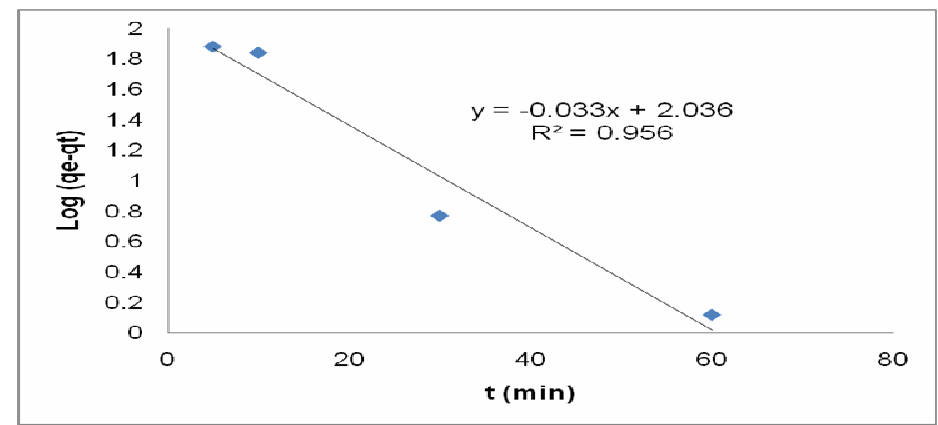

Figure 5 b. Pseudo $1^{\text {st }}$ order graphical illustration for synthetic calcite.

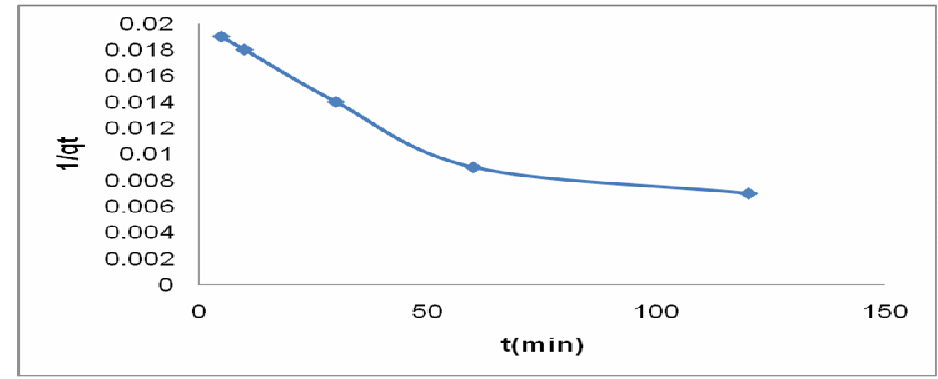

Figure 5c. Pseudo $2^{\text {nd }}$ order graphical illustration for natural calcite.

Bull. Chem. Soc. Ethiop. 2012, 26(2) 


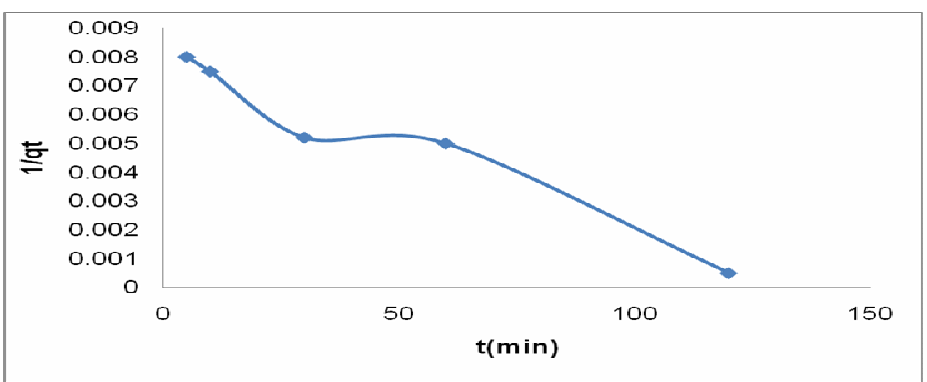

Figure 5d. Pseudo $2^{\text {nd }}$ order graphical illustration for synthetic calcite.

\section{Adsorption kinetics}

The kinetic data have been determined and the results are summarized in Tables $6 \mathrm{a}$ and $6 \mathrm{~b}$. Sorption of $\mathrm{Pb}$ (II) on calcite follows pseudo first order reaction. The model adequately fits the data over the entire course of the experiment with high correlation coefficients of 0.94 and 0.96 for natural and synthetic calcite materials. This result is in good agreement with the work carried out by other researchers [32] as sorption of $\mathrm{Pb}$ (II) on soils follow first order reaction. The values of the rate constants for pseudo first order reaction of 0.15 and $0.08 \mathrm{~min}^{-1}$ show that the two reactions are rapid [33].

Table 6a. Pseudo $1^{\text {st }}$ and $2^{\text {nd }}$ order kinetic data for the sorption of $\mathrm{Pb}$ (II) on natural and synthetic calcite samples.

\begin{tabular}{|l|l|l|l|l|}
\hline $\mathrm{t}(\min )$ & $\begin{array}{l}\text { Log } \mathrm{q}_{\mathrm{e}}-\mathrm{q}_{\mathrm{t}} \\
\text { natural }\end{array}$ & $\begin{array}{l}\text { Log } \mathrm{q}_{\mathrm{e}}-\mathrm{q}_{\mathrm{t}} \\
\text { synthetic }\end{array}$ & $1 / \mathrm{q}_{\mathrm{t}}$ natural & $1 / \mathrm{q}_{\mathrm{t}}$ synthetic \\
\hline 5 & 1.99 & 1.88 & 0.019 & 0.008 \\
\hline 10 & 1.97 & 1.84 & 0.014 & 0.0052 \\
\hline 30 & 1.91 & 0.77 & 0.014 & 0.0052 \\
\hline 60 & 1.63 & 0.12 & 0.009 & 0.005 \\
\hline 120 & 0 & 0 & 0.007 & 0.0005 \\
\hline
\end{tabular}

Table $6 \mathrm{~b}$. Correlation coefficient and rate constant of pseudo $1^{\text {st }}$ and 2 nd order adsorption kinetic data for the sorption of $\mathrm{Pb}(\mathrm{II})$ on synthetic and natural calcite samples.

\begin{tabular}{|l|l|l|}
\hline Pseudo $1^{\text {st }}$ order & Natural & Synthetic \\
\hline Correlation coefficient $\mathrm{R}^{2}$ & 0.9422 & 0.9565 \\
\hline $\mathrm{k}_{1}(1 / \mathrm{min})$ & 0.153 & 0.076 \\
\hline Pseudo $2^{\text {nd }}$ order & & \\
\hline Correlation coefficient $\mathrm{R}^{2}$ & 0.877 & 0.5636 \\
\hline $\mathrm{k}_{2}(1 / \mathrm{min})$ & $5.5 \times 10^{-7}$ & $5.5 \times 10^{-8}$ \\
\hline
\end{tabular}

Spectroscopic studies

The Infrared spectra for both samples show the characteristic band of calcite 2351, 1798, 1422 1428 , and $712-876 \mathrm{~cm}^{-1}$. The IR result of the natural sample indicate the presence of silicate which is absent in the synthesized calcite. There is another peak indicating the presence of metal in the spectra of both the sorbed natural and synthesized calcite. The results are presented in Tables $7 \mathrm{a}$ and $7 \mathrm{~b}$. 
Table 7a. IR data for the natural and synthetic calcites before sorption.

\begin{tabular}{|l|l|l|}
\hline Peaks for natural $\left(\mathrm{cm}^{-1}\right)$ & Peaks for synthetic $\left(\mathrm{cm}^{-1}\right)$ & Functional group \\
\hline $2361-2982$ & $2361-2982$ & Stretching vibration of adsorbed water molecules \\
\hline 2351 and 1798 & 1797 & Indicate the presence of calcite \\
\hline $1422-1428$ & 1425 & Characteristics band of calcite \\
\hline $712-876$ & $712-875$ & Characteristic band of calcite \\
\hline $664-417$ & & Indicating the presence of silicate materials \\
\hline
\end{tabular}

Table $7 \mathrm{~b}$. IR data for the calcites after sorption.

\begin{tabular}{|l|l|l|}
\hline Peaks for natural $\left(\mathrm{cm}^{-1}\right)$ & Peaks for synthetic $\left(\mathrm{cm}^{-1}\right)$ & Functional group \\
\hline $2513-1637$ & $2284-1633$ & Stretching vibration of adsorbed water molecules \\
\hline 1420 & 1428 & Characteristics band of calcite \\
\hline 1051 & 1051 & Indicating the presence of metal \\
\hline $712-875$ & $712-875$ & Characteristic band of calcite \\
\hline
\end{tabular}

The result of X-ray diffraction (XRD) analysis shows $\mathrm{CaCO}_{3}$ as the major mineral constituent as seen in the spectra (Figure 6a and 6b). The scan shows pronounced peaks at $2 \theta$ values of 27.71 and 45.12 for the natural and synthetic calcites, this is conformity with the JCPDS standard for calcite and the result of Al-Degs et al. [25]. The analysis confirmed the structure of the pronounced $\mathrm{CaCO}_{3}$ in natural sample as orthorhombic while that of the synthetic as hexagonal.

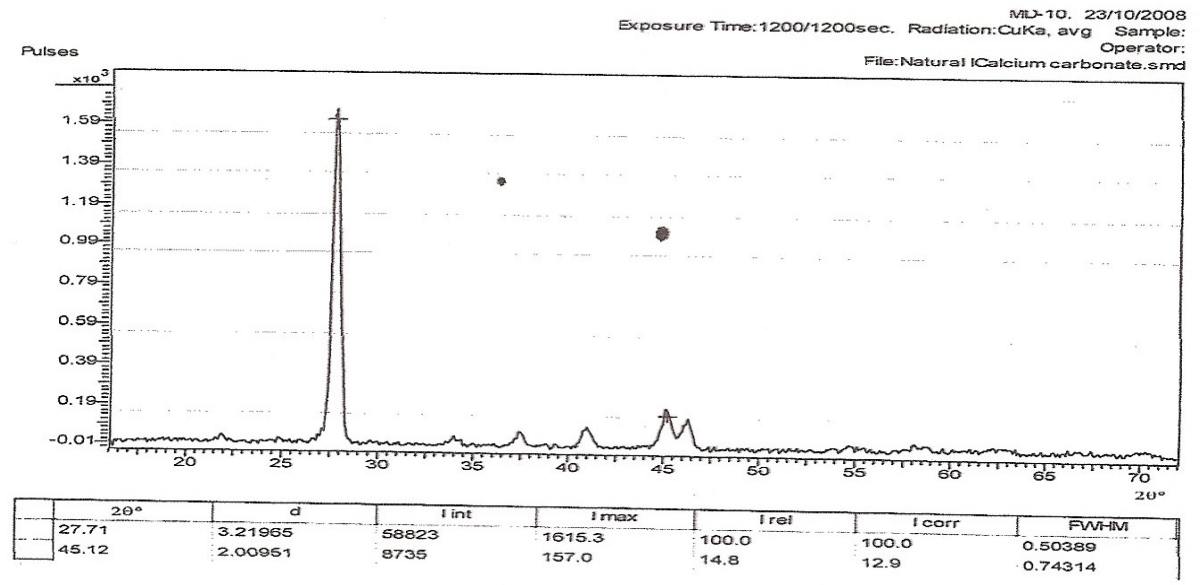

Figure 6a. X-ray diffraction (XRD) scan for natural calcite. 


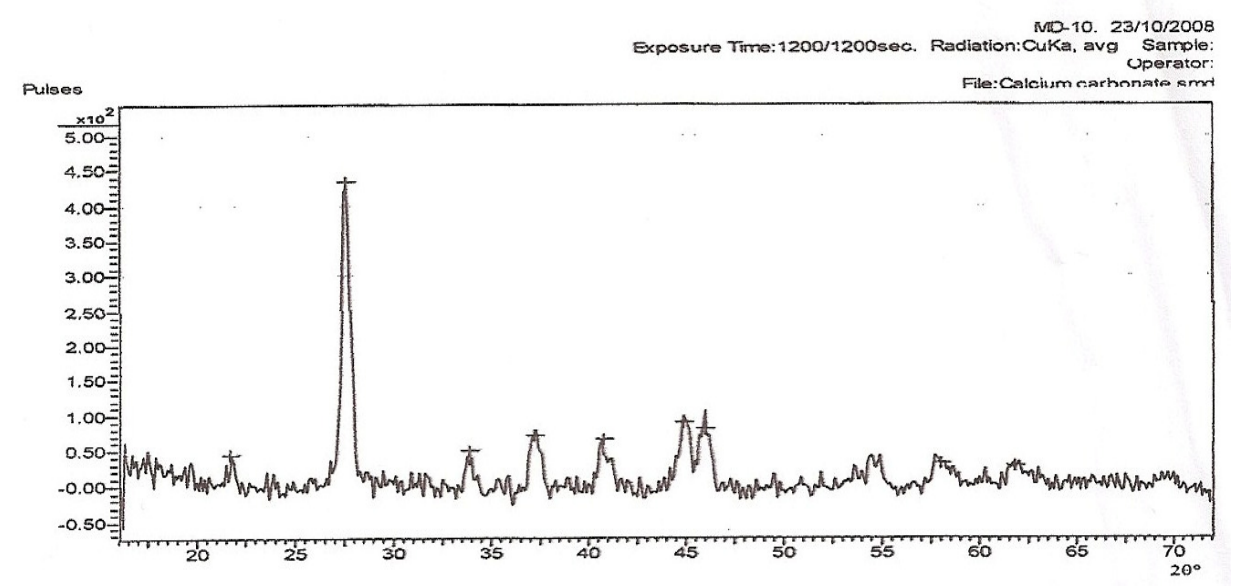

Figure 6b. X-ray diffraction (XRD) scan of synthetic calcite.

\section{Results of desorption experiment}

The results of desorption process at different $\mathrm{pH}$ values are illustrated in Figure 7. The results of the desorption experiment show that the percentage of $\mathrm{Pb}$ (II) released into the solution decreases with increase in $\mathrm{pH}$. Desorption was rapid at low $\mathrm{pH}$ values and then decrease to a constant at higher $\mathrm{pH}$ values. There is rapid release of $\mathrm{Pb}(\mathrm{II})$ when the $\mathrm{pH}$ is acidic while the rate was very slow as the $\mathrm{pH}$ becomes alkaline because the co-precipitation of $\mathrm{PbCO}_{3}$ could be attributed to this [34]. Generally the amount of $\mathrm{Pb}$ (II) desorbed is lower than those adsorbed, these desorption experiments suggest a very strong bond of the $\mathrm{Pb}$ (II) ion to the calcite surface, i.e. forming a inner sphere complex at the calcite surface. At low pH values (1-3) good percentage of the lead can be removed from calcite surfaces. This indicates that calcite material can be easily regenerated for subsequent re-use. About $95 \%$ of the $\mathrm{Pb}$ (II) was desorbed using 4 $\mathrm{M} \mathrm{HNO}_{3}$ within $2 \mathrm{~h}$ of contact time. The material was also found to be stable as less than $0.4 \%$ of it was dissolved in the process. The values of the desorption index (DI) were also calculated for the various $\mathrm{pH}$ values in order to evaluate the degree of reversibility of $\mathrm{Pb}$ (II)-calcite sorption process [34]. Desorption index is the ratio of percentage of lead on calcite at end of sorption to percentage of lead on calcite at end of desorption. A sorption process is considered to be completely reversible when DI equals 1 . The degree of irreversibility of a sorption reaction increases as DI value deviates from 1. In this particular case, the DI values for natural calcite ranged from 1.11 to 3.33 , while that of synthetic calcite ranged from 1.01 to 4.0 when $\mathrm{pH}$ was decreased from 8.43 to 2.56 . These results imply that a reversible process was obtained in alkaline medium and the degree of reversibility decreases with increase in acidity or decrease in alkalinity.

The reversibility of the sorption process of both natural synthetic calcites has been determined. This was done by calculating the desorption index (DI), expressed as the ratio of sorbed $\mathrm{Pb}$ (II) and aqueous $\mathrm{Pb}$ (II) before and after desorption for a given calcite particle loading [34].

$\mathrm{DI}=(\%$ total $\mathrm{Pb}$ sorbed after sorption $) /(\%$ total $\mathrm{Pb}$ left on calcite after desorption $)$. 


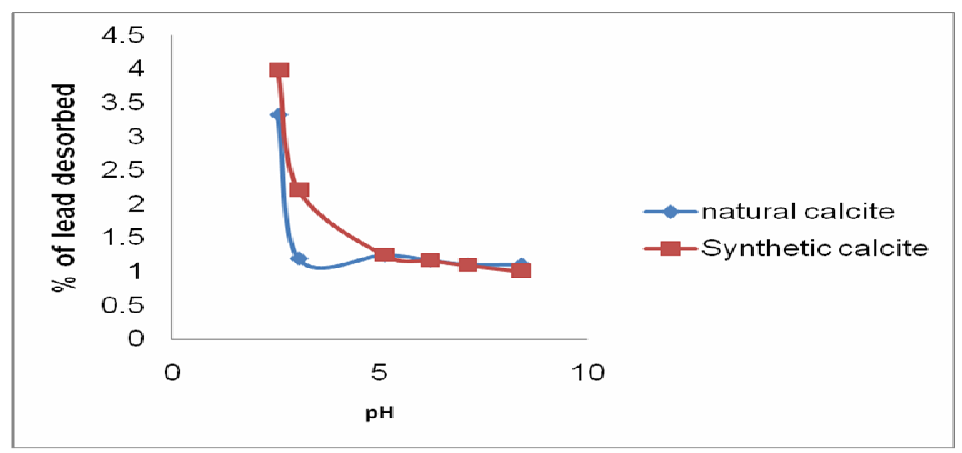

Figure 7. The curve for $\%$ desorbed vs $\mathrm{pH}$ for natural and synthetic calcite.

\section{CONCLUSIONS}

Calcite has been found to be a good adsorbent for $\mathrm{Pb}(\mathrm{II})$. The data revealed that the sorption process is not affected by ionic strength and $\mathrm{pH}$. The immobilization process was rapid, nearing completion in two hours and the larger the particle size the more the surface area and thus the more the quantity sorbed per mg of the material. Synthetic calcite with higher percentage of calcium carbonate than natural calcite has more affinity for $\mathrm{Pb}^{2+}$ and the quantity sorbed per $\mathrm{mg}$ of the synthetic calcite in all cases is more than that of natural calcite. The adsorption isotherm studies also showed that the synthetic calcite shows good adsorption capacity for lead than natural with high values of $\mathrm{Q}_{\max }$ and $\mathrm{K}_{\mathrm{r}}$ approximately 268 and $9.69 \mathrm{mg} / \mathrm{g}$, respectively. The sorption kinetics studied showed that the reaction followed an overall pseudo-first order reaction. The results of desorption experiment indicated that desorption process is rapid at lower $\mathrm{pH}$ values with good percentage of $\mathrm{Pb}$ (II) being removed from the surface of the material. The spent calcite was also found to be regenerable.

\section{REFERENCES}

1. Othmer, K. Cellulose in Encyclopaedia of Chemistry Technology, Vol. 6, 2nd ed., John Wiley and Sons: New York; 1964; p 593.

2. Nriagu, J.O. Nature 1989, 338, 47.

3. Behrman, R.E.; Robert, M.N. Textbook of Paediatrics, 17th ed., Elsevier: Philadelphia; 2004; p 2352.

4. Bryce, S.D.; Desphande, R.R.; Hughes, J.; Waldron, H.A. Loncet 1977, 1, 1159.

5. Erickson, M.M.; Poklis, A., Dickinson, A.W.; Hullman, L.S. Pediatoric Ros. 1983, 17, 177.

6. Boekx, R.L. Anal. Chem. 1986, 58, 274A.

7. Gupta, V.K.; Jain, C.K.; Ali, I.; Sharma, M.; Saini, V.K. Water Res. 2003, 37, 4038.

8. Ametyst Galleries, The mineral Calcite.galleries.com.web services. Retrieved at http://mineral.galleries.com/minerals/carbonat/carcite/calciteht on 06-01-2009.

9. Uygur, V.; Rimmer, D.L. Eur. J. Soil Sci. 2000, 51, 511.

10. Sanchez, A.G.; Ayuso, E.A. Miner. Eng. 2002, 15, 539.

11. Comans, R.N.; Midelburg, J.J. Geochim. Cosmochim. Acta 1987, 51, 2587.

12. Brady, P.V.; Papenguth, H.W.; Kelly, J.W. Geochem. 1999, 14, 569.

13. Stephen, A.C.; James, F.E.; Lamb, D.Mc.; Karen K. Int. J. Coal Geol. 2005, 67, 17. 
14. Rouff, A.A.; Elzinga, E.J.; Reeder, R.J.; Fisher, N.S. Geochim. Cosmochim. Acta 2005, 69, 5173.

15. Papadopoulous, D.L.; Rowell, R. J. Soil Sci. 1989, 40, 39.

16. Kozar, S.; Bilinski, H.; Brancia, M. Mar. Chem. 1992, 40, 21.

17. Rouff, A.A.; Elzinga, E.J.; Reeder, R.J. Geochim. Cosmochim. Acta 2006, 70, 2715.

18. Ababio, O.Y. New School Chemistry, Africana First Publishers Limited: Nigeria; 2001; p 457.

19. Paola, Z.; Francesca, P. Geochemistry 2005, 20, 507.

20. Suzana, Z.; Nikola, K. Application of Mass Titration to the Point of Zero Charge Determination, Academic Press: Zagreb, Yugoslavia; 1991, p 233.

21. Marek, K. J. Colloid Interface Sci. 2002, 253, 77.

22. Yavuz, O.; Guzel, R.; Aydin, F.; Tegin,I.; Ziyadanogullari, R. Polish J. Environ. Stud. 2007, $16,467$.

23. Rangel-Porras, G.; Garcia-Magno, J.B.; Gonzalez-Munoz, M.P. Desalination 2010, doi:10.1016/j.desal.2010.04.043.

24. Kozar, S.; Bilinski, H.; Branica, M., Mar. Chem. 1992, 40, 215.

25. Al-Degs, Y.S.; El-Barghouthi, M.I.; Ayman, A.I.; Khraisheh, A.M.; Walker, G.M. Water Res. 2006, 40, 2645.

26. Rashed, M.N. Environmentalist 2001, 21, 187.

27. Rouff, A.A.; Reeder, R.J.; Fisher, N.S. J. Colloid Inter. Sci. 2005, 286, 61.

28. Wooyong, U.M.; Charalambos, P. Am. Miner. 2003, 88, 2028.

29. Strawn, D.G.; Sparks, D.L. J. Colloid Inter. Sci. 1999, 216, 257.

30. Stumm, W. Chemistry of the Solid - Water Interface Processes at the Water and ParticleWater Interface in Natural Systems, John Wiley and Sons: New York; 1992.

31. Frimmel, F.H.; Huber, L. Environ. Int. 1996, 22, 507.

32. Strawn, D.G.; Sparks, D.L. Soil Sci. Soc. Am. J. 2000, 64, 144.

33. Pigna, M.; Krishnamurti, G.S.; Violante, A. Soil Sci. Soc. Am. J. 2006, 70, 2017.

34. Rouff, A.A.; Reeder, R.J.; Fisher, N.S. Aquatic Geochem. 2002, 8, 203. 